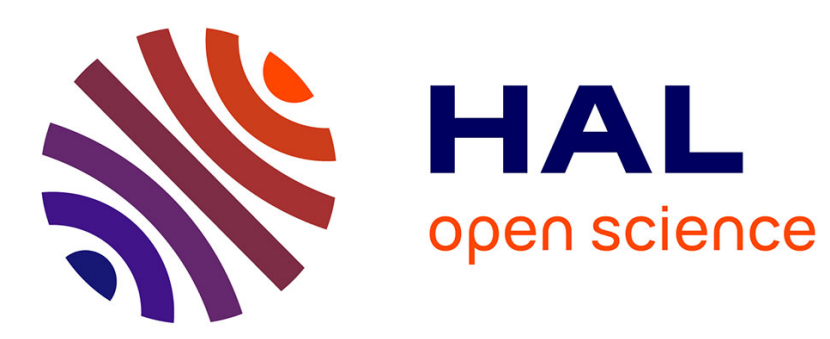

\title{
Mergers in the GB Electricity MArket: effects on Retail Charges
}

\author{
Evens Salies
}

\section{To cite this version:}

Evens Salies. Mergers in the GB Electricity MArket: effects on Retail Charges. Applied Economics, 2008, 40 (11), pp.1483-1490. 10.1080/00036840600794322 . hal-00581941

\section{HAL Id: hal-00581941 \\ https://hal.science/hal-00581941}

Submitted on 1 Apr 2011

HAL is a multi-disciplinary open access archive for the deposit and dissemination of scientific research documents, whether they are published or not. The documents may come from teaching and research institutions in France or abroad, or from public or private research centers.
L'archive ouverte pluridisciplinaire HAL, est destinée au dépôt et à la diffusion de documents scientifiques de niveau recherche, publiés ou non, émanant des établissements d'enseignement et de recherche français ou étrangers, des laboratoires publics ou privés. 


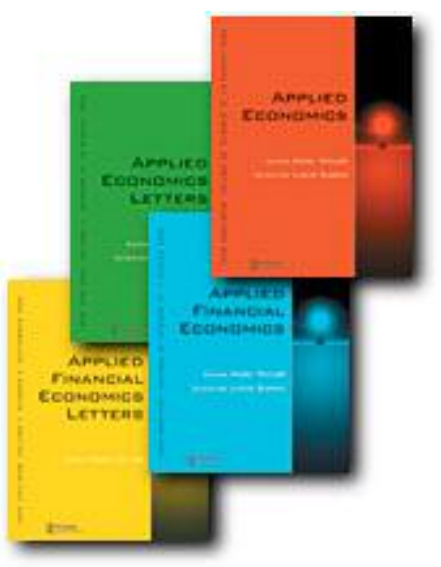

Mergers in the GB Electricity MArket: effects on Retail Charges

\begin{tabular}{|r|l|}
\hline Journal: & Applied Economics \\
\hline Manuscript ID: & APE-05-0247.R1 \\
\hline Journal Selection: & Applied Economics \\
\hline JEL Code: & $\begin{array}{l}\text { C31 - Cross-Sectional Models|Spatial Models < , L22 - Firm } \\
\text { Organization and Market Structure: Markets vs. Hierarchies; } \\
\text { Vertical Integration < }\end{array}$ \\
\hline Keywords: & Energy Competition, Retail Pricing, Vetically integrated firms \\
\hline
\end{tabular}

powersed by ScholarOne
Manuscript Central 


\section{Mergers in the}

\section{GB Electricity Market: effects on Retail Charges}

The opening up of the UK residential electricity sector in 1999 prompted several studies of the impact this had on both the level and structuring of retail charges, and on incumbent players' market power. Drawing on observations of regional tariffs for the month of January 2004, this paper supports previous conclusions based on simulated retail charges, looking at the response of real tariffs to distribution and transmission costs, customer density, and the length of low voltage underground circuit. We also investigate whether vertically integrated suppliers have a particular effect on charges ceteris paribus the effect of cost drivers and supplier-related factors. 


\section{INTRODUCTION}

The GB residential electricity market was opened to competition in May 1999. This had an immediate impact on the level of tariffs and services offered to consumers. The wave of mergers and acquisitions which followed raised concerns about the potential detrimental effect on end-customers. Although much research has been devoted to switching behaviour (Giulietti et al., 2006; Waterson, 2003; Ofgem, 2001, 2002, 2003), third-degree price discrimination and incumbents' market power (Otero and Waddams Price, 2001), little information is available about the effect of ownership structures on tariffs.

Oligopoly models show that the proposition that a merger enables firms to exploit economies of scale is not convincing if the merger does not also generate technical synergies. These synergies would lead to lower charges to customers (Spector, 2003; see also references herein). A study by Azzam and Rosebaum (2001) which considers the link between efficiency to concentration points out however that it is difficult to discriminate empirically between collusion and cost-efficiency as variables relating to price and profitability. The retail electricity market is a case in point, as high switching costs favour collusive behaviour, thus maintaining high prices.

Using 2002 price data Salies and Waddams Price (2004) examine similarities between the effects of brand coefficients on retail electricity prices within existing ownership groups but find that evidence of this is weak. Relying on tariffs levels from January 2004, the present paper contributes to the discussion by highlighting the effect of mergers on tariffs in a more efficient way. We test for the specific average effect of several ownership groups on regional electricity retail charges after 
controlling for cost drivers, economies of scale and customer density. Particular attention is given to the effect of the creation of EDF Energy, the merged London Electricity and SEEBOARD group of companies. In broad terms, we conjecture that if technical synergies exist between distribution networks owned by EDF Energy (situated in contiguous regions: London, East and South-East England), they should result in lower prices.

This paper is structured as follows. Section II briefly reviews the changes in ownership structures that occurred in the GB electricity sector between May 2002 and January 2004. We focus on the probable effect of these changes on the degree of competition and remaining incumbents' market power. We then introduce data, an econometric model and the hypotheses to be tested in section III. Results are given and discussed in section IV, before the conclusion in section V.

\section{CHANGES IN MARKET STRUCTURE}

The ownership structure of each supplier is summarised in the following table and compared with that of April-May 2002, being the period analysed by Salies and Waddams Price (2004).

[Insert Table 1]

A more detailed picture of the ownership structures of residential distributors and suppliers in GB as at January 2004 is given in the Appendix (see also Electricity Association, 2003a, b). At the intersection of any given row and column one can see whether a supplier (row) is an incumbent in the distribution region (column). A supplier may not be present in the selected region, as is the case for Basic Power. 
Concentration increased from April 2002 as a result of acquisitions, with at the most five ex-Public Electricity Suppliers and three new entrants in most areas, in addition to internet and other suppliers (ex-Public Electricity Suppliers, hereafter "ex-PES", are also known as Regional Electricity Companies). Almost all suppliers operate in the 14 distribution regions that make us England, Scotland and Wales. For reasons unknown to the authors, Basic Power was not operating in Scotland at the time of the study, which remains the case.

In April 2004 Scottish Hydro Electric-Southern Electric (SSE) acquired Atlantic Electric and Gas. Powergen purchased TXU's British generation and retail operations. These mergers raise competition concerns although they may have different detrimental effects given that they involve firms with significantly different market shares. A merger between two firms, each with relatively high market share, may have less impact on competition than one in which a large supplier merges with a smaller rival (RBB, 2002).

The magnitude of the coefficient applied to the ownership group dummies in comparison with the coefficient of other groups will help us to test the data for particular merger effects. ${ }^{1}$

\section{DATA AND ECONOMETRIC MODEL}

The retail charges pertain to 14 regions, with up to eight brand names per region. We consider here a single payment method (standard credit) at three levels of consumption. The distribution charges were taken from distributors' published statements of charges for connection to and use of the distribution system (Ofgem, 2004). Constituting $15-30 \%$ of a customer's final bill, these vary across the 
distribution regions according to the charges levied by the local distribution company, but are levied in the same manner to all suppliers using that distribution network. Generally the tariffs have two components: a charge per consumer and a charge per unit of electricity carried. We note that prepayment distribution charges differ from credit and direct debit charges. ${ }^{2}$ Transmission charges form approximately $13 \%$ of the invoice and vary from region to region. Charge levels are taken from the National Grid Transco web site (see National Grid Transco, 2003), and are those levied for the period 16:00 hours to 19:00 hours. Descriptive statistics are shown in Table 2.

[Insert Table 2]

For each level of consumption $q=1650,3300$, and $4950 \mathrm{kWh}$, we estimate the following model:

$$
c_{r j}(q)=\alpha_{1 m} d_{r m}(q)+\alpha_{2} t_{r}(q)+\alpha_{3} n_{r}+\alpha_{4} u_{r}+\alpha_{5} i_{i j}+\sum_{g} \alpha_{6 g} o_{g j}+\varepsilon_{r j}
$$

where indices $r$ and $j$ denote distribution region and supplier, respectively. The payment method is standard credit. " $(q)$ " specifies variables the value of which varies with $q .^{3}$ In addition:

$c_{r j}=$ retail charge in region $r$ from supplier $j$

$d_{r}=$ distribution charge in region $r$

$t_{r}=$ transmission charge in region $r$

$n_{r}=$ total number of distribution customers per $\mathrm{km}^{2}$ in region $r$ (density)

$u_{r}=$ length of underground circuit in region $r$

$i_{r j}=1$ if supplier $j$ is the incumbent in region $r ; 0$ otherwise (incumbency dummy)

$o_{g j}=1$ if supplier $j$ belongs to ownership group $g ; 0$ otherwise (group dummy) 
We estimate three regression equations, one for each simulated level of annual demand, relating retail charges to the cost elements which we could identify, to market characteristics and to incumbency and group dummies.

Salies and Waddams Price (2004) estimated a model similar to (1) with brand instead of group dummies. Brand dummies capture any effect of suppliers reflected in tariffs (including costs of purchasing electricity). Our model gives us an opportunity to test whether suppliers that are not vertically integrated with other market participants tend to price less compared with integrated suppliers. In this model we replaced brand dummies with fewer group dummies that measure the impact on retail charges of the various ownership groups present in the market at the time of the analysis. There are five mutually exclusive ownership groups: Powergen, Scottish Hydro Electric and Southern Electric, Scottish Power, EDF Energy, and Innogy, plus the three non-ex-PES companies, as listed in Table 1.

Given the findings of Salies and Waddams Price (2004), we expect costs variations across regions to be closely mirrored in tariff variations ( $\alpha_{1}$ to be close to 1 , and $\alpha_{2}$ not exceeding one third, reflecting the shorter consumption period to which transmission charges correspond). We allow for both the number of customers and the distribution area using a ratio of the two. It is expected that denser (urbanised) areas allow suppliers to reduce per-customer marketing costs for a given network size, which would be indicated by a negative value for $\alpha_{3}$. The length of low voltage underground circuit is used as a proxy for the size of the network. Underground circuit length has a very close correlation to the number of distribution customers (the correlation coefficient equals 0.88 ). Its effect on charges shall be measured by 
$\alpha_{4}$. A negative value for this coefficient would more generally indicate economies of scale.

The additional power of incumbents (the ex-PES), who had retained a market share of between $50 \%$ and $85 \%$, would be reflected in higher tariffs and a positive coefficient for the incumbency dummy, $\alpha_{5}$. A positive and significant value for this coefficient may reflect the positive costs of switching from one ex-PES to another.

Using data from April 2002, Salies and Waddams Price (2004) test for heterogeneity between suppliers by examining the significance of brand dummy coefficients. Here, we test the hypothesis of whether vertical integration has a relatively significant effect on charges using $\alpha_{6}$. Unlike the previous study which relied on signs of the estimated coefficients on brand dummies, the present analysis shows some improvement as it statistically tests for the significance of group dummy coefficients; group dummies replace brand dummies. We note that our model may be seen as a constrained version of a model with brand dummies.

We have not included a constant; thus, no base group is considered. This allows us to avoid near-colinearity problems and vacuous interpretation of the constant. Following the Salies and Waddams Price (2004) we estimated a two-equation seemingly unrelated regression equation (SURE) model for standard and direct debit tariffs. We only report results of the standard credit equation.

As there is a possibility of non-constant residual variance within each equation resulting from the spatial dimension of our data, we tested for conditional heteroskedasticity of unknown form within each equation using White's (1980) test. 
We reject homoskedasticity at the $5 \%$ level of significance in the direct debit equation at $1650 \mathrm{kWh}$. We may interpret this result as a stronger attempt from supply businesses to differentiate their tariffs in this market. As will be shown later, this result shows regional incumbents still enjoy market power, particularly in the direct debit market where most switching has occurred. The model's coefficients are reported in Table 3.

\section{RESULTS AND DISCUSSION}

First we consider the responses of retail charges to distribution and transmission charges. As expected, the coefficient on distribution charges is significantly different from zero at the $5 \%$ level of significance. If we assume a $95 \%$ confidence interval centred about one, distribution costs are almost fully passed on to customers, except in the direct debit and prepayment equations at $1650 \mathrm{kWh}$. With regard to transmission charges, our results are also similar to Salies and Waddams Price (2004), with a coefficient about one third due to the short consumption period to which these charges correspond (peak period from 16:00 to 19:00 hours). If in each equation at $3300 \mathrm{kWh}$ we multiply by three the estimated coefficient on the transmission variable then we obtain a value that ranges from about 0.7 to 0.8 .

[Insert Table 3]

We find economies of density at $1650 \mathrm{kWh}$ and less significantly at $3300 \mathrm{~kW}$.

Closely related, the negative impact on retail charges of the length of the underground circuit in all markets would reflect economies of scale: a customer's bill is lower in distribution regions that have more kilometres of circuit underground. The low significance of the coefficient applied to density might result from the excessive 
correlation between this variable and circuit's length variables. The existence of those economies leads us to reject the hypothesis that urban and rural customers benefit equally from competition. In any event, NAO (2001, p.8) reported that rural customers are less likely to change their electricity supplier than those who live in urban areas because many customers change their supplier in response to a visit from a sales agent, and direct marketing of electricity has so far been less intensive in rural areas.

This negative relationship between retail charges and both the size of the network and the number of customers per $\mathrm{km}^{2}$ reflects first technical economies at the distribution stage: heavy investments create an incentive for distributors to spread their costs among a large number of connected households. This situation could support the increasing concentration through horizontal integration in the retail sector; given the existence of decreasing per customer distribution charges paid by suppliers, they have an interest in servicing a large number of customers. The twocomponent structure of distribution tariffs in all but the Sweb regions implies technical economies of scale, in that the "per unit" distribution charge necessarily decreases when the amount of energy supplied to consumers increases.

As expected, Atlantic Electric and Gas and Basic Power have the lowest impact on charges with potential average annual savings (see Waterson, 2003) of up to $£ 50$, as between the cheapest and the most expensive supplier. Note that these savings do not account for consumer perception of switching costs. This difference was highest in the direct debit market at 4950kWh (we do not report this result). Conversely, the effect of Innogy and Powergen groups on charges is greater or equal to the average effect. This seems consistent with integrated suppliers charging higher prices raising 
competition concerns. It is well known that the existence of consumer switching costs creates a further incentive for firms to grab more customers, which necessarily gives an advantage to older suppliers in the market (Farrell and Klemperer, 2004). Ofgem (2003, p.38) reports that more households are switching to non-prepayment markets and low-income customers switch less often.

Interestingly, EDF Energy group has, on average, a lower impact on charges than SSE and Innogy. We suspect a more efficient vertically integrated structure and pricing strategy. Note that EDF Energy includes the Seeboard and Eastern distribution businesses that are in neighbouring regions. It is worth noting, as Spector (2003) emphasises, that the proposition that a merger allows firms to exploit economies of scale is not convincing if the merger does not also generate technical synergies, through learning for example. Technical synergies may exist between distribution networks owned by EDF Energy because they are in contiguous regions (London, the East and South East). In addition, EDF Energy holds generation assets, giving it the ability to bypass the volatile and often illiquid electricity exchanges in order to hedge its customer base.

SSE also seems efficient at low consumption levels compared with Powergen, Scottish Power, Innogy and British Gas, but overall less efficient than the EDF Energy group. Unlike this latter entity, SSE owns very distant networks, one in Scotland and the other in the South of England, which, in accordance with our previous discussion, would not favour technical synergies.

\section{CONCLUSION}


Using regional observations on tariffs offered in December 2003, the present paper set out to investigate the particular effect of various integrated structures on the relationship between annual retail charges and cost drivers. We find evidence of different pricing strategies by the various ownership groups, which suggests that the effect on retail charges of integrated suppliers varies depending on the spatial dispersion of the merged networks.

Overall these results support Salies and Waddams Price (2003, 2004) who also pointed out the negative (respectively positive) effect on unit rates and bills of a change in the number of customers (respectively the distribution area). Our density variable, however, provides a more flexible interpretation as the particular influence on charges in rural (less dense) areas proves to be significant. Alongside this variable, the size of the underground network leads to a similar result as the number of customers: coefficient estimates range from -0.7 to -0.3 . For example, if the underground circuit increases by $3,000 \mathrm{~km}$, then retail charges would decrease by $£ 1$ in the standard credit market at $1,650 \mathrm{kWh}$.

We could bring more information to the discussion by extending the range of consumption levels considered or using longitudinal data. This would have the further advantage of increasing the number of observations for brands such as Manweb, SWEB, Swalec, and Seeboard. 


\section{REFERENCES}

Azzam, A. and Rosenbaum, D. (2001), Differential efficiency, market structure and price, Applied Economics, 33, 1351-1357.

Electricity Association (2003a), Electricity Companies in the United Kingdom - A brief Chronology, //www.electricity.org.uk/media/documents/pdf/chronology.pdf

Electricity Association (2003b), Who Owns Whom in the UK electricity industry, //www.electricity.org.uk

Farrell, J. and Klemperer, P. (2004), Coordination and lock-in: competition with switching costs and Network effects, //elsa.berkeley.edu/users/farrell/

Giulietti, M., Waddams Price, C. and Waterson, M (2006), Consumer Choice and Industrial Policy: A Study of UK Energy Markets, The Economic Journal, 115 (506), 949-968.

NAO (2001), Giving domestic customers a choice of electricity supplier, //www.nao.org.uk/publications/nao_reports/00-01/000185.pdf

National Grid Transco (2003, March), The statement of Use of System Charges, Issue 3. //www.nationalgrid.com/uk/indinfo/charging

Ofgem (2001), How many people are changing supplier?, //www.ofgem.gov.uk/prices/switching.htm

Ofgem (2002), Electricity supply competition: an Ofgem occasional paper, //www.ofgem.gov.uk/temp/ofgem/cache/ cmsattach/1804_83occasional.pdf

Ofgem (2003), Domestic gas and electricity supply competition Recent developments, //www.ofgem.gov.uk/temp/ofgem/cache/cmsattach/3833_DCMR04july.pdf

Ofgem (2004, April), Domestic competitive market review 2004 - A review document, 
//www.ofgem.gov.uk/temp/ofgem/cache/cmsattach/6741_DCMR_publication_Ch 1_to_3.pdf

Otero, J. and Waddams Price, C. (2001), Price discrimination, regulation and entry in the U.K. residential market, Bulletin of Economic Research 53(3), 161-75.

RBB Economics (2002, November), Switching costs and merger assessment - don't move the goal posts, Brief 06.

Salies, E. and Waddams Price, C. (2003), Pricing structure in the deregulated UK electricity market, City University, London, Economics Dept. discussion paper 03/02.

Salies, E. and Waddams Price, C. (2004), Charges, costs and market power: the deregulated UK electricity retail market, The Energy Journal, 25(3), 19-35.

Spector, D. (2003), Horizontal mergers, entry, and efficiency defences, International Journal of Industrial Organization, 21, 1591-1600.

Vega-Cervera, J. A. and Jurado-Málaga, A. (2001), Aspects of convergence in European electricity prices - an empirical approach, Economies et Sociétés, Economie de l'énergie series, 8(1-2), 35-53.

Waterson, M. (2003), The role of consumers in competition and competition policy, International Journal of Industrial Organization, 21, 129-50.

White, H. (1980), A heteroskedasticity-consistent covariance matrix estimator and a direct test for heteroskedasticity, Econometrica, 48(4), 817-38. 
Acknowledgements. I would like to thank Catherine Waddams Price from the Centre for Competition Policy to whom I am greatly indebted. I am also grateful to Adam Cutforth. This research was undertaken with support from Sebastian Eyre and Katharine Morrison from the Great Britain gas and electricity consumer association Energywatch. The author accepts responsibility for any remaining errors. 


\section{Endnotes}

1. This group acquired SWALEC in 2000 thus we do not ignore the influence of the SWALEC acquisition.

2 . For Scottish Power and Scottish Hydro regions, we employed data from the 2002-03 period as this was the only data available to us in the appropriate format (p/kWh) when completing the present study. Prepayment distribution standing charges were replaced with their non-prepayment equivalent when the data was missing, which occurs in four regions. At $1,650 \mathrm{kWh}$, this substitution is fairly accurate, as the extra charge for prepayment customers does not exceed $£ 10$, i.e. $15 \%$ of distribution charges (or less than $3 \%$ of retail charges).

${ }^{3}$. Given the non-linear structure of most tariffs offered by network utilities (see Wilson, 1997), these models have some advantage over models considering a single mean level of consumption. V.Cervera and J-Málaga (2001) and Ofgem's works also consider more than one level of annual demand. This methodology is appropriate as most tariffs intersect at some level of consumption reflecting various pricing strategies and tactics to attract targeted consumers; some suppliers prefer to target low energy demand customers while others offer attractive tariffs to customers whose annual demand exceeds an average level known to suppliers. 
Table 1. Ownership structure for main supply brands in April 2002 and January

$2004^{(a)}$

\begin{tabular}{ll}
\hline April 2002 & January 2004 \\
\hline & Ex-PES
\end{tabular}

London Electricity (SWEB)

EDF Energy (London Energy, SWEB

Energy, SEEBOARD Energy) ${ }^{(b)}$

\section{SEEBOARD}

ScottishPower (Manweb)

ScottishPower (Manweb)

Npower (Northern, Yorkshire)

Npower (Northern, Yorkshire)

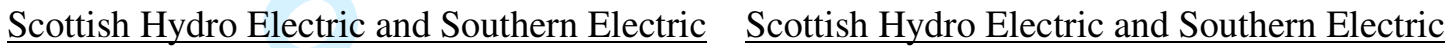

(SWALEC)

(SWALEC)

Powergen

Powergen (Eastern, Norweb)

TXU-Europe (Eastern, Norweb)

Non ex-PES

Amerada, Atlantic Electric and Gas, Utility ${ }^{(c)}$ Atlantic Electric and Gas, Utility Link

Link (Basic Power), British Gas

(Basic Power), British Gas

${ }^{(a)}$ Mergers are underlined, and acquisitions represented with parentheses, with the name of the owner before the parenthesis.

${ }^{\text {(b) }}$ LE Group completed its acquisition of SEEBOARD in July 2002. Before that date, SEEBOARD was held by American Electric Power. It became SEEBOARD

Energy Ltd in 2002. LE Group changed its name to EDF Energy in 2003, and its supply brand, London Electricity, changed its name to London Energy.

(c) Amerada became part of Powergen and was re-branded Powergen in 2003. 
Table 2. Descriptive statistics - January $2004^{(\text {a) }}$

\begin{tabular}{|c|c|c|c|c|}
\hline & & & Minimum & Maximum \\
\hline & Mean & Std. Dev. & Value & Value \\
\hline Total charge pe & & & & \\
\hline $1650 \mathrm{kWh}$ & 14593 & 1244 & 12300 & 17900 \\
\hline $3300 \mathrm{kWh}$ & 24553 & 1906 & 21100 & 29500 \\
\hline $4950 \mathrm{kWh}$ & 34520 & 2927 & 29700 & 42000 \\
\hline Total charge pe & & & & \\
\hline $1650 \mathrm{kWh}$ & 13470 & 1145 & 11400 & 16300 \\
\hline $3300 \mathrm{kWh}$ & 23215 & 2036 & 19300 & 28000 \\
\hline $4950 \mathrm{kWh}$ & 32939 & 19077 & 27200 & 39700 \\
\hline Total charge pe & & & & \\
\hline $1650 \mathrm{kWh}$ & 15922 & 1885 & 11800 & 22000 \\
\hline $3300 \mathrm{kWh}$ & 26547 & 2308 & 21900 & 33900 \\
\hline $4950 \mathrm{kWh}$ & 37187 & 2890 & 31000 & 45900 \\
\hline Distribution cho & & & & \\
\hline $1650 \mathrm{kWh}$ pa & 3793 & 632 & 2687 & 4735 \\
\hline $3300 \mathrm{kWh}$ pa & 5919 & 1079 & 4275 & 7933 \\
\hline $4950 \mathrm{kWh}$ pa & 8044 & 1732 & 5720 & 11449 \\
\hline Distribution cho & & & & \\
\hline $1650 \mathrm{kWh}$ pa & 4045 & 891 & 2687 & 5833 \\
\hline $3300 \mathrm{kWh}$ pa & 6170 & 1128 & 4275 & 7933 \\
\hline $4950 \mathrm{kWh}$ pa & 8296 & 1680 & 5720 & 11449 \\
\hline
\end{tabular}

Transmission charge per annum

$1650 \mathrm{kWh}$

$2009 \quad 957$

136

3478 
$3300 \mathrm{kWh}$

$4950 \mathrm{kWh}$

Distribution customers, 000

Size of distribution area, in $\mathrm{km}^{2}$

Density (distribution customers / $\mathrm{km}^{2}$ )

Underground circuit (km)

${ }^{\text {(a) }}$ Charges are inclusive of VAT.

$\begin{array}{llll}4018 & 1915 & 272 & 6956 \\ 6028 & 2873 & 409 & 10434\end{array}$

$\begin{array}{llll}1961 & 679 & 673 & 3381\end{array}$

$\begin{array}{llll}15928 & 11300 \quad 667 & 54500\end{array}$

$\begin{array}{llll}356 & 780 & 12 & 3124\end{array}$

$\begin{array}{llll}22081 & 8466 & 8917 & 36302\end{array}$

\section{Table 3. Standard Credit; Dependent variable: annual bill}

\section{Annual consumption}

\section{\begin{tabular}{lll}
\hline $1650 \mathrm{kWh}$ & $3300 \mathrm{kWh}$ & $4950 \mathrm{kWh}$
\end{tabular}}

Distribution Charge

\begin{tabular}{llllll}
\hline .86 & $* * *$ & 1.03 & $* * *$ & .89 & $* * *$
\end{tabular}

$(.12)$

$(.07)$

$(.07)$

Transmission Charge

.54

.26

$* * * \quad .16$

$(.08)$

(.03)

Density (customers $/ \mathrm{km}^{2}$ ) $\quad-.23$

$$
* * \quad-.16
$$

$(.09)$

$(.08)$

Underground Lines $(\times 1000) \quad-.32$

(.09)

$* * * \quad-.38$

$-.69$

7.51

(.09)

Incumbent

(2.64)

18.69

29.74

(1.82)

Suppliers $(£)$

Sempra Energy, etc. (Atlantic $101.46 \quad$ *** $167.07 \quad * * * \quad 256.51 \quad$ *** Electric and Gas) 
(7.65)

(6.41)

(8.16)

$\begin{array}{lcccccc}\text { Utility Link (Basic Power) } & 116.68 & * * * & 176.89 & * * * & 260.51 & * * * \\ & (7.64) & & (6.34) & & (8.06) & \\ & 111.06 & * * * & 191.49 & * * * & 296.07 & * * * \\ \text { Powergen } & (7.44) & & (6.40) & & (8.14) & \\ & 104.51 & * * * & 182.75 & * * * & 284.68 & * * * \\ \text { SSE } & (7.46) & & (6.43) & & (8.19) & \end{array}$

Scottish Power

119.88

*** $\quad 186.18$

*** $\quad 276.83$

(7.44)

(6.40)

(8.15)

EDF Energy

103.30

*** $\quad 175.69$

*** 272.72

(7.48)

(6.44)

(8.20)

Innogy

111.94

$* * *$

182.27

*** $\quad 286.07$

(7.58)

(6.40)

(8.14)

Centrica (British Gas)

$$
113.74
$$

*** $\quad 179.28$

*** $\quad 270.44$

(7.45)

(6.41)

(8.16)

Adj. $R^{2}$

.731

.909

.919

Notes: standard errors in parentheses. '*' = significant at the $10 \%$ level. '**' = significant at the $5 \%$ level. ' $* * * '=$ significant at the $1 \%$ level. 
Appendix. Ownership structure in the UK residential electricity market at December 2003

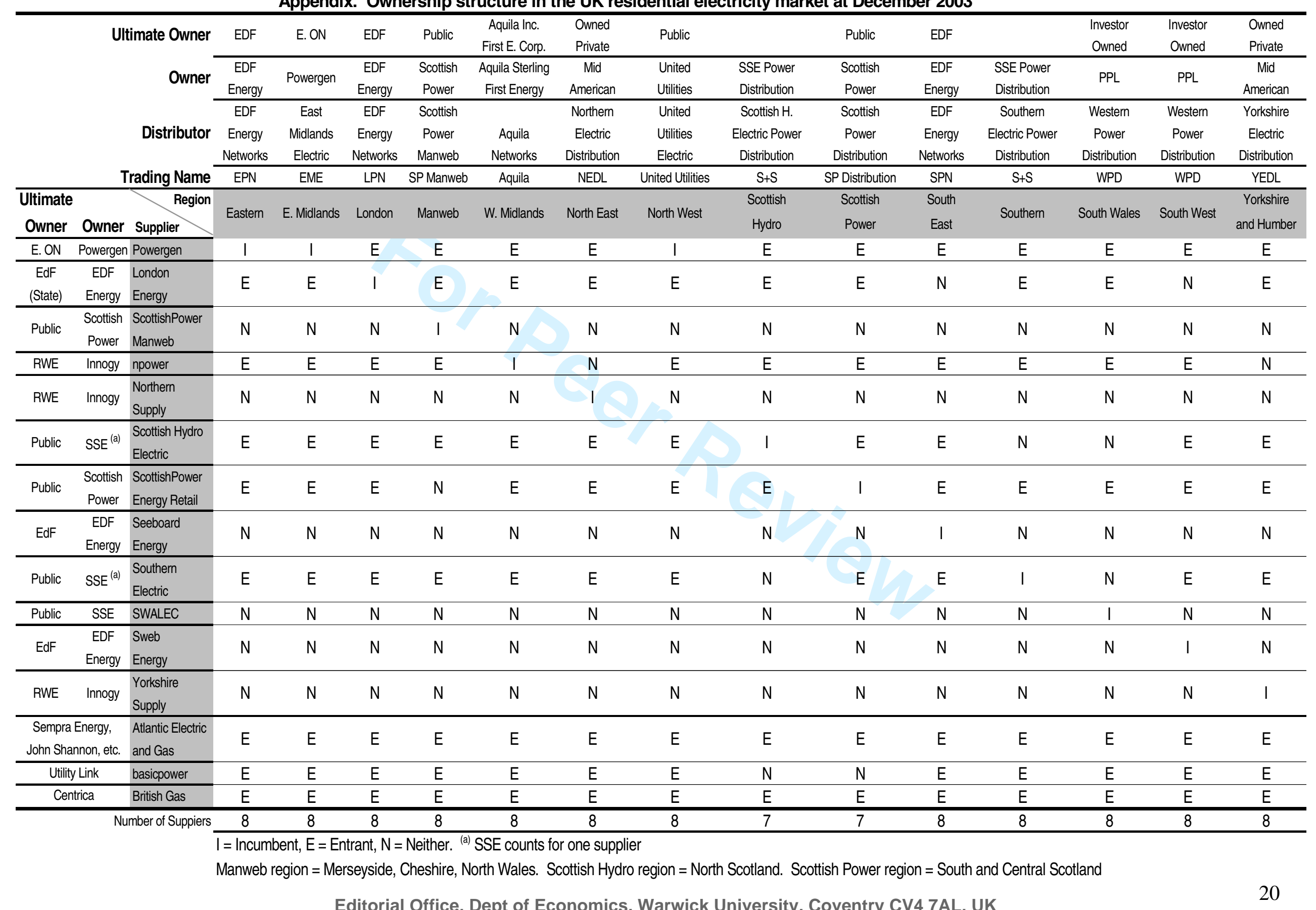

Editorial Office, Dept of Economics, Warwick University, Coventry CV4 7AL, UK 